\title{
Laser transformation hardening effect on hardening zone features and surface hardness of tool steel AISI D2
}

\author{
D. Lesyk ${ }^{1}$, V. Dzhemelinskyi ${ }^{1}$, S. Martinez $^{2}$, A. Lamikiz ${ }^{2}$, O. Danyleiko ${ }^{1}$, V. Hyzhevskyi ${ }^{1}$ \\ 1 - Igor Sikorsky Kyiv Polytechnic Institute, Kyiv, Ukraine; \\ 2 - University of the Basque Country, Bilbao, Spain
}

Received: 15 March 2017 / Accepted: 29 March 2017

\begin{abstract}
The relationship of technological input regimes of the laser transformation hardening on change the hardening depth, hardening width, and hardening angle, as well as surface hardness of the tool steel AISI D2 using multifactor experiment with elements of the analysis of variance and regression equations was determined. The laser transformation hardening process implemented by controlling the heating temperature using Nd:YAG fiber laser with scanner, pyrometer and proportional-integraldifferential controller. The linear and quadratic regression models are developed, as well as response surface to determine the effect of the heating temperature and feed rate of the treated surface on the energy density of the laser beam, hardening depths, hardening width, hardening angle, and surface hardness are designed. The main effect on the energy density of the laser beam has a velocity laser treatment, on the other hand, the main effect on the geometrical parameters of the laser hardened zone and surface hardness has temperature heating are shown. The optimum magnitudes of the heating temperature $\left(1270{ }^{\circ} \mathrm{C}\right)$ and feed rate of the treated surface $(90 \mathrm{~mm} / \mathrm{min}$ ) for laser transformation hardening of the tool steel AISI D2 using fiber laser with scanner were defined.
\end{abstract}

Keywords: laser transformation hardening; surface layer; hardened zone; hardness; tool steel AISI D2

\section{Introduction}

One of the most important problems solved by mechanical engineering is to improve surface microrelief and to increase physical and mechanical properties of the surface layer of metal products, which work in extreme conditions, by means of the developing and application of modern technologies for surface treatment. Solving this problem will allow to increase both operating properties and competitiveness of the manufactured products. One of the technological solutions to improve the wear resistance of the working surfaces of parts is the hardening of the surface layer by changing its structure [1].

Application of highly-concentrated energy sources of plasma flow [2], electron beam [3] and laser [4] radiation ensure high levels increasing the hardness of metal parts, but not always promote improving surface microrelief. These high-energy methods surface treatment provide an opportunity the local hardening and promote increasing productivity processes. Developed modern laser engineering systems have some important advantages (uniform hardening depth, no vacuum environment, the possibility to transfer energy beam over long distances) compared to the plasma treatment, electron-beam treatment and other methods of surface thermal hardening [5]. Laser surface hardening of the tool steels by means of the laser transformation hardening (LTH) without melting [6] or with melting surface [7], and shock peening [8], by analogy with other types of hardening is the formation of the austenitic structure with the dissolution of carbide phases during rapid-action heating and its following transformation to martensite structure during cooling due to absorbing and transferring energy high concentrations to thin surface layer. Herewith time heating and cooling is minor, and practically absent dwell time at heating. These conditions provide high heating and cooling rates of the processed surface areas.

High-alloyed tool steel AISI D2 with high chromium content is widely used in mechanical engineering. In particular, at the manufacturing of cutting edge blanking dies and dies of cold and hot pressing. These tool steels should be characterized by high hardness and wear resistance with sufficient viscosity in hot conditions and the possibility to maintain these properties over a significant period of working (exploitation). The cost of die tool is $8 . .20 \%$ of the cost forgings, and suspension of operation of the die tools in consequence of breakage is $\sim 30 \%$, wear loss is $\sim 18 \%$, unsuccessful selection of steel for dies is $\sim 11 \%$ and from non-compliance of heat treatment regime is $\sim 6 \%[9]$. 
It is known [10] that the melting of the surface layer of high-alloy steels causes reduction surface hardness due to complete dissolution of carbides and a significant increasing in residual austenite. Tool steel AISI D2 is no exception. Melted layer of the tool steel AISI D2 has dendritic austenite structure with between dendritic interlayers of carbides cementite type. Diffusion of chromium occurs a quite slowly. As a result, chromium carbides don't have time to form through high cooling rate. In connection with this, high-alloy steels should be hardened without melting or with the minimal melting of surfaces [11].

Therefore, laser transformation hardening process is desirable to perform via the method of maintaining a constant temperature in the laser beam area by controlling the heating temperature treated surface [12].

Purpose

To determine the relationship of technological input LTH regimes at the action of the fiber laser with scanner on change the hardening depth, hardening width, and hardening angle, as well as surface hardness of the tool steel AISI D2 using multifactor experiment with elements of the analysis of variance and regression equations.

\section{Methodology}

Plane specimens of tool steel AISI D2 (dimensions $69 \times 9 \times 69 \mathrm{~mm}$ ) were initially heated to $850{ }^{\circ} \mathrm{C}$, then slowly cooled in the furnace to $650{ }^{\circ} \mathrm{C}\left(10^{\circ} \mathrm{C}\right.$ per hour $)$, and then cooled in the environment air. This thermal treatment results in a typical microstructure contained the alloyed $\alpha$-ferrite and carbides. The chemical composition and mechanical properties of the studied steel at $T=20^{\circ} \mathrm{C}$ are listed in Table 1 .

Table 1

Chemical composition and mechanical properties of the tool steel AISI D2

\begin{tabular}{|c|c|c|c|c|c|c|c|c|c|c|c|c|c|c|c|c|}
\hline $\begin{array}{c}\mathrm{C} \\
(\%)\end{array}$ & $\begin{array}{c}\mathrm{Cr} \\
(\%)\end{array}$ & $\begin{array}{l}\text { Mo } \\
(\%)\end{array}$ & $\begin{array}{c}\mathrm{V} \\
(\%)\end{array}$ & $\begin{array}{l}\mathrm{Mn} \\
(\%)\end{array}$ & $\begin{array}{c}\mathrm{Si} \\
(\%)\end{array}$ & $\begin{array}{c}\mathrm{Ni} \\
(\%)\end{array}$ & $\begin{array}{c}\mathrm{Cu} \\
(\%)\end{array}$ & $\begin{array}{l}\mathrm{P}, \mathrm{S} \\
(\%)\end{array}$ & $\begin{array}{l}\mathrm{Fe} \\
(\%)\end{array}$ & $\begin{array}{c}\sigma_{\mathrm{Y}} \\
(\mathrm{MPa})\end{array}$ & $\begin{array}{c}\sigma_{\mathrm{U}} \\
(\mathrm{MPa})\end{array}$ & $\begin{array}{c}\delta \\
(\%)\end{array}$ & $\begin{array}{c}E \\
(\mathrm{GPa})\end{array}$ & $\mu$ & $\mathrm{HRC}_{1}$ & $\begin{array}{l}H \mu_{0.05} \\
(\mathrm{GPa})\end{array}$ \\
\hline$\stackrel{n}{n}$ & $\stackrel{n}{=}$ & $\stackrel{m}{\infty}$ & $\stackrel{N}{\grave{0}}$ & $\stackrel{0}{+}$ & 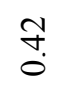 & $\frac{n}{0}$ & $\begin{array}{l}0 \\
\stackrel{0}{0}\end{array}$ & $\begin{array}{l}\text { Oे } \\
\stackrel{0}{V}\end{array}$ & $\underset{i}{+}$ & $\stackrel{\overbrace{}}{\widehat{N}}$ & $\stackrel{\circ}{\frac{1}{\Lambda 1}}$ & $\frac{0}{\wedge 1}$ & ஓ્ & 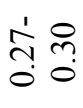 & $\stackrel{0}{\sigma}$ & ஸे \\
\hline
\end{tabular}

$\sigma_{\mathrm{Y}}$ is the tensile yield strength, $\sigma_{\mathrm{U}}$ is the tensile ultimate strength, $\delta$ is relative elongation, $E$ is the Young's modulus, $\mu$ is Poisson's ratio, HRC is the surface hardness, $H \mu_{0.05}$ is the microhardness in the specimens' cross-sections

Measured and calculated magnitudes of surface hardness (HRC) and microhardness $(H \mu)$ the surface layer in cross section (according to Vickers hardness test procedure) are given in Table 1.

Laser surface hardening process of parts was carried out by a high power Nd:YAG fiber laser in continuous mode (Rofin Sinar FL010 fiber laser) with a maximum power output of $1 \mathrm{~kW}$ and a wavelength $\lambda=1.07 \mu \mathrm{m}$ (Fig. 1a). A galvanometric 2D scanner produced by Scanlab was placed into the special machine Kondia Aktinos B500 (Fig. 1b) with numerical control for moving treated surface. The scanner head is composed by a collimating lens, focus lenses, and two galvanometers. The scanning velocity and width of the laser beam was controlled using the software of the scanner.

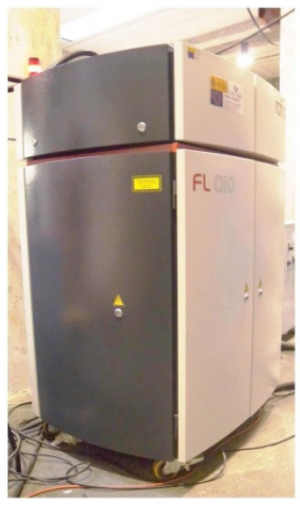

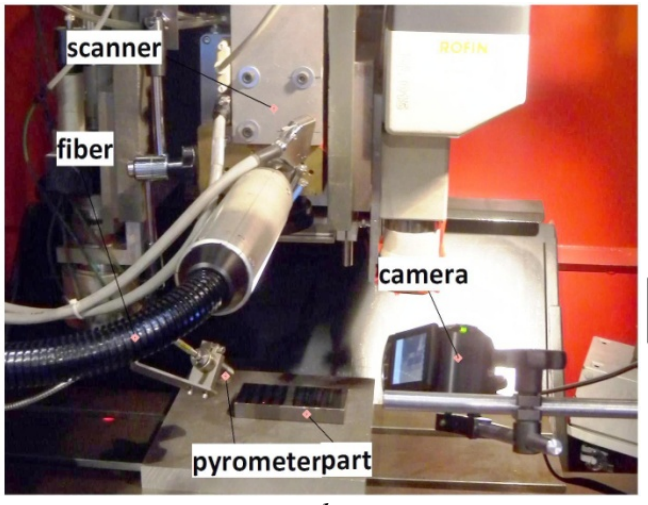

$b$

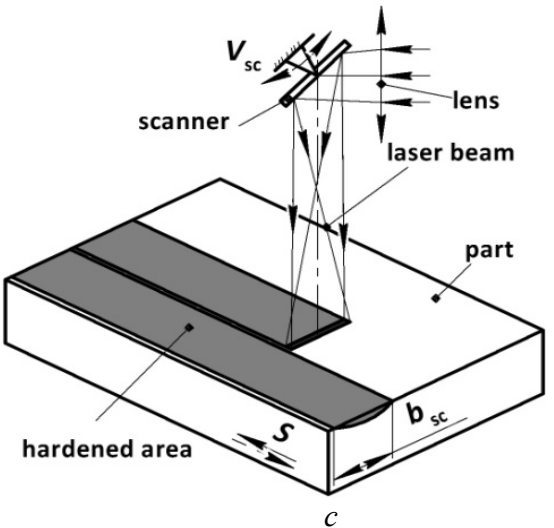

Рис. 1. Laser surface hardening process: a - fiber laser, b- machine center, c-scheme of LTH

Measured magnitudes of the heating temperature by two-color pyrometer Impac Igar 12LO during LTH were transferred through a proportional-integral-differential controller on a special board of the collection and data processing, which transformed the digital signal to analog signal laser power required to maintain a constant temperature in the laser beam area (Fig. 2).

To determine the effect of LTH regimes (factors) on the geometrical parameters hardening zones, as well as the magnitudes of the energy density of the laser beam and the surface hardness (dependent output variables) of the studied 


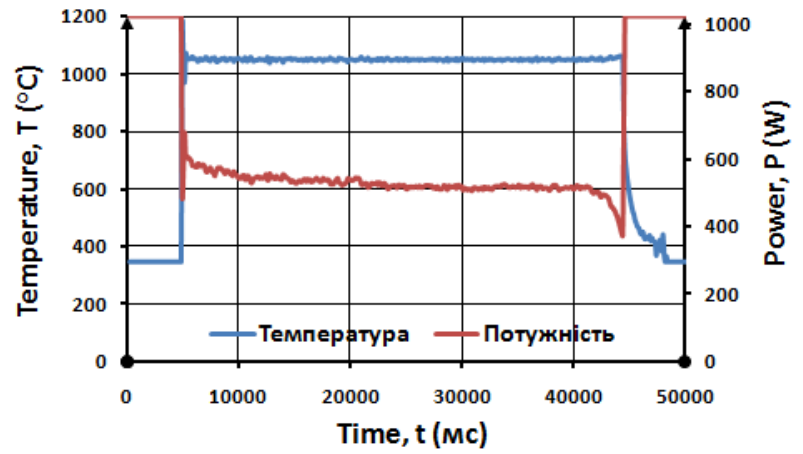

Fig. 2. Real time measured temperature and controlled laser power steel was used methods of mathematical planning of the experiment because of a large number of technological regimes.

These methods allow reducing the number of needed experiments, to establish the relationship between the studied parameters and LTH regimes, and optimize process.

Experimental studies were conducted based on the design of a multifactor experiment. Herewith as input factors (independent input variables) were used the following technological regimes of LTH process: the heating temperature and feed rate of the treated surface (Table. 2).

Table 2

Variation limits of factors

\begin{tabular}{|l|c|c|c|c|}
\hline \multicolumn{1}{|c|}{ Factors } & \multicolumn{4}{|c|}{ Levels factors } \\
\cline { 2 - 5 } & $\mathrm{x}_{\min }(-1)$ & $\mathrm{x}_{\max }(+1)$ & $\mathrm{x}_{0}(0)$ & $\Delta \mathrm{x}$ \\
\hline $\mathrm{A}\left(\mathrm{x}_{1}\right)$ is the heating temperature $T\left({ }^{\circ} \mathrm{C}\right)$ & 1200 & 1340 & 1270 & 70 \\
\hline $\mathrm{B}\left(\mathrm{x}_{2}\right)$ is the feed rate of the treated surface $S(\mathrm{~mm} / \mathrm{min})$ & 40 & 140 & 90 & 50 \\
\hline
\end{tabular}

The magnitudes of other technological processing regimes (scanning velocity and width of the laser beam, focused position, and etc.) were installed constant, which were defined based on previous studies and recommendations [5]. The LTH process was carried out was carried out with a scanning velocity $1000 \mathrm{~mm} / \mathrm{s}$ which produced the track $10 \mathrm{~mm}$ wide on the specimen surface.

The studied output parameters (dependent output variables) were energy density of the laser beam $\left(E_{l b}\right)$ and hardening depth $\left(h_{h}\right)$, hardening width $\left(b_{h}\right)$ and hardening angle $\left(\alpha_{h}\right)$ (Fig. 3), as well as surface hardness (HRC) of the laser track (Table. 3).

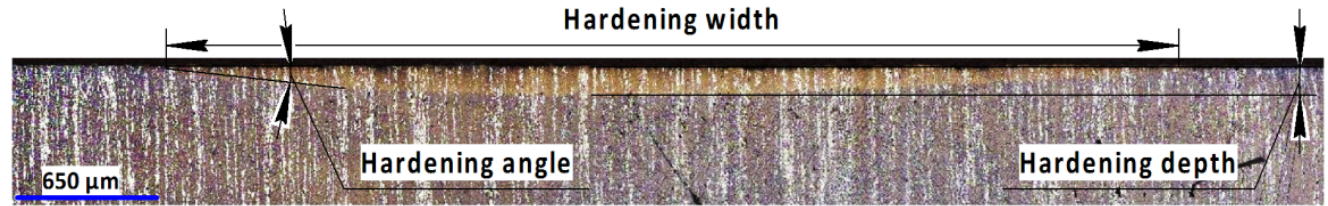

Fig. 3. Geometrical parameters of the laser hardened zone

The energy density $\left(\mathrm{KJ} / \mathrm{cm}^{2}\right)$ of the laser beam was determined by the formula [12]:

$$
E_{l b}=P / d_{l b} \cdot S,
$$

where $P$ is the laser power (laser power magnitudes was determined by means of a special software), W; $d_{\mathrm{lb}}$ is the diameter of the laser beam, $\mathrm{cm} ; S$ is the feed rate of the treated surface, $\mathrm{cm}$.

Table 3

Design matrix with code independent input variables and dependent output variables

\begin{tabular}{|c|c|c|c|c|c|c|c|c|c|c|}
\hline \multirow{2}{*}{$\begin{array}{c}\text { Experim- } \\
\text { ental No. }\end{array}$} & \multirow{2}{*}{$\begin{array}{c}\text { Run } \\
\text { order }\end{array}$} & \multicolumn{2}{|c|}{ Coded variable } & \multicolumn{2}{|c|}{ Actual variable } & \multicolumn{5}{|c|}{ Experimental measured responses } \\
\cline { 3 - 12 } & & $\mathrm{x}_{1}(T)$ & $\mathrm{x}_{2}(S)$ & $\mathrm{x}_{1}(T)$ & $\mathrm{x}_{2}(S)$ & $\mathrm{y}_{1}\left(E_{l b}\right) \kappa \mathrm{J} / \mathrm{cm}^{2}$ & $\mathrm{y}_{2}\left(h_{h}\right) \mu \mathrm{m}$ & $\mathrm{y}_{3}\left(b_{h}\right) \mu \mathrm{m}$ & $\mathrm{y}_{4}\left(\alpha_{h}\right)^{\circ}$ & $\mathrm{y}_{5}(\mathrm{HRC})$ \\
\hline LTH7 & 4 & - & - & 1200 & 40 & 72 & 170 & 9500 & 3,5 & 47 \\
\hline LTH8 & 7 & - & 0 & 1200 & 90 & 39 & 140 & 7800 & 2,5 & 45.2 \\
\hline LTH9 & 5 & - & + & 1200 & 140 & 28 & 80 & 7600 & 2 & 33.8 \\
\hline LTH10 & 9 & 0 & - & 1270 & 40 & 78 & 380 & 10500 & 8,2 & 51.2 \\
\hline LTH11 & 1 & 0 & 0 & 1270 & 90 & 40 & 310 & 10200 & 7,1 & 52.1 \\
\hline LTH12 & 8 & 0 & + & 1270 & 140 & 30 & 230 & 9500 & 5,5 & 54.8 \\
\hline LTH13 & 6 & + & - & 1340 & 40 & 87 & 290 & 10100 & 7 & 51.5 \\
\hline LTH14 & 3 & + & 0 & 1340 & 90 & 42 & 270 & 10000 & 6,8 & 52.4 \\
\hline LTH15 & 2 & + & + & 1340 & 140 & 29 & 240 & 9500 & 6,2 & 52.7 \\
\hline
\end{tabular}

Linear and quadratic regression model obtained in the form:

$$
\begin{gathered}
y=b_{0}+b_{1} x_{1}+b_{2} x_{2}+b_{12} x_{1} x_{2}, \\
y=b_{0}+b_{1} x_{1}+b_{2} x_{2}+b_{12} x_{1} x_{2}+b_{11} x_{1}{ }^{2}+b_{22} x_{2}{ }^{2},
\end{gathered}
$$


where $y$ is the response calculated by model (dependent output variables), $b_{0}$ is the constant regression coefficient; $b_{1}, b_{2}, b_{12}, b_{11}, b_{22}$ is the regression coefficients; $x_{1}, x_{2}$ are the variables corresponding to independent input variables.

The geometrical features of the laser hardened zone were investigated using optical microscope-profilometer Leica DCM3D with 10XLD confocal lens and appropriate software. The surface hardness prior to and after LTH process was measured using a Computest SC tester at a load on indenter of $10 \mathrm{~N}$ at the dwell time of $3 \mathrm{~s}$.

Design matrix evaluation for surface response linear and quadratic models, analysis of model statistics and diagnostic plots, as well as creation of model graphs and optimization of experimental results were performed using a Design-Expert statistical software program, in particular response surface methodology (RSM). RSM designs help to determine the relationships between the input factors and one or more measured responses.

\section{Results and discussion}

The typical geometric dimensions of the laser hardened zones in cross section obtained by a high power fiber laser with a galvanometric scanner at high scanning velocities are showed in Table 4. It is known that temperature peaks at the terminations are lower than the center of the track at high scanning velocities [5]. As a result, the maximum hardened thickness is in the center of the track.

Table 4

Hardened zone at different $\mathrm{LTH}$ regimes

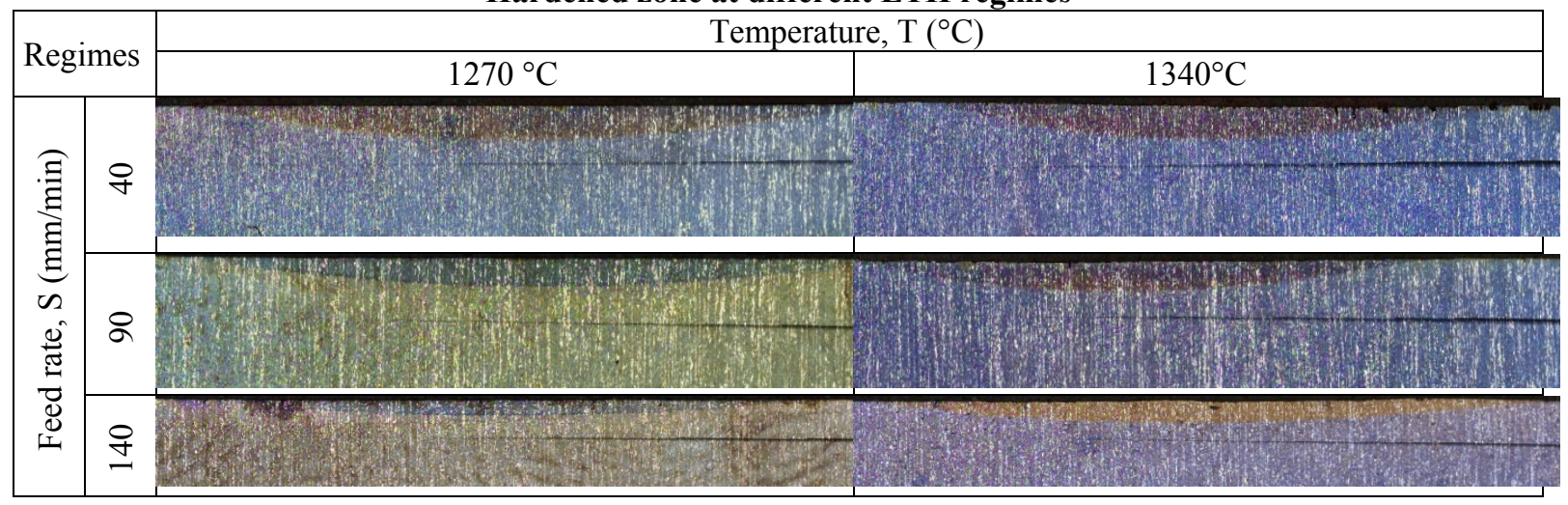

In order to determine the heating temperature and feed rate of the treated surface effect on energy destiny, geometrical parameters of the laser hardened zone and surface hardness, the design of experiment full factorial threelevel design with response surface methodology and analysis of variance (ANOVA) was applied. ANOVA results of RSM linear and quadratic models are given in Table 5.

ANOVA for response surface linear and quadratic models

Table 5

\begin{tabular}{|c|c|c|c|c|c|c|c|c|c|c|}
\hline Model & Linear & Quadratic & Linear & Quadratic & Linear & Quadratic & Linear & Quadratic & Linear & Quadratic \\
\hline Measured responses & \multicolumn{2}{|c|}{$\mathrm{y}_{1}\left(E_{l b}\right)$} & \multicolumn{2}{|c|}{$\mathrm{y}_{2}\left(h_{h}\right)$} & \multicolumn{2}{|c|}{$\mathrm{y}_{3}\left(b_{h}\right)$} & \multicolumn{2}{|c|}{$\mathrm{y}_{4}\left(\alpha_{h}\right)$} & \multicolumn{2}{|c|}{$\mathrm{y}_{5}(\mathrm{HRC})$} \\
\hline F value & 16.70 & 221.91 & 2.74 & 18.20 & 4.30 & 11.53 & 4.21 & 25.66 & 12.99 & 36.61 \\
\hline p-value prob. $>\mathrm{F}$ & 0.004 & 0.0005 & 0.152 & 0.018 & 0.075 & 0.035 & 0.077 & 0.011 & 0.008 & 0.006 \\
\hline $\mathrm{R}^{2}$ & 0.90 & 0.99 & 0.62 & 0.96 & 0.72 & 0.95 & 0.71 & 0.97 & 0.88 & 0.98 \\
\hline Adjusted $\mathrm{R}^{2}$ & 0.85 & 0.99 & 0.39 & 0.91 & 0.55 & 0.86 & 0.54 & 0.93 & 0.81 & 0.95 \\
\hline Predicted $\mathrm{R}^{2}$ & 0.65 & 0.96 & -0.56 & 0.61 & 0.17 & 0.45 & -0.05 & 0.72 & 0.61 & 0.80 \\
\hline Adequate precision & 9.74 & 35.74 & 4.87 & 12.87 & 5.93 & 10.64 & 5.63 & 13.64 & 10.04 & 16.86 \\
\hline
\end{tabular}

ANOVA showed that designed both the linear and quadratic regression model response of the energy density magnitude of the laser beam $\left(E_{l b}\right)$ and surface hardness (HRC) are significant because the probability values of models are less than 0.05 (Table. 5). Moreover, the determination coefficients are in the range $0 \leq \mathrm{R}^{2} \leq 1$, adequate precision ratios are greater than 4 and values of the variation coefficients of models are comparatively low that allows to state about a high accuracy and reliability of the results. It should be noted that obtained by linear regression models response of the hardening depths $\left(h_{h}\right)$, hardening width $\left(b_{h}\right)$ and hardening angle $\left(\alpha_{h}\right)$ are less important compared to developed quadratic regression models because of a smaller number of freedom degrees. In particular, Table 4 shows that the linear regression models response of the hardening depths, hardening width and angle don't provide conditions according to Fisher criterion. Furthermore, the predicted determination coefficient extends beyond the conditions $0 \leq \mathrm{R}^{2} \leq 1$. In applying the quadratic regression models these disadvantages are eliminated because the quadratic models with five degrees of freedom for Fisher criterion is more significant compared with linear models with three degrees of freedom. A value of significance models is less than 0.05 that indicate about their adequacy. Thus, quadratic regression models response of the hardening depths, hardening width and angle are significant. 
Moreover, correlation coefficients $\left(\mathrm{R}^{2}\right)$ in the quadratic regression models are very close 1 in comparison with linear regression models that indicate about the high adequacy of the results.

As a consequence, the results obtained according to ANOVA showed that the main influence on the magnitude the energy density of the laser beam has the feed rate of the treated surface (velocity of laser heat treatment). On the other hand, the main influence on the magnitude hardening depths, hardening width, hardening angle and surface hardness have the heating temperature regardless of the investigated regression models.

Linear and quadratic regression equations (mathematical models) for the response of the energy density of the laser beam $\left(E_{l b}\right)$, hardening depths $\left(h_{h}\right)$, hardening width $\left(b_{h}\right)$, hardening angle $\left(\alpha_{h}\right)$ and surface hardness (HRC) of the tool steel AISI D2 according to full factorial three-level design for the coded values of factors are as follows:

$$
\begin{gathered}
E_{\text {лл }}=49.44+3.17 A-25.0 B-3.5 A B, \\
h_{3}=234.44+68.33 A-48.33 B+10.0 A B, \\
b_{3}=9411.11+783.33 A-583.33 B+325.0 A B, \\
\alpha_{3}=5.54+2.0 A-0.83 B+0.17 A B, \\
H R C=50.97+2.45 A+1.1 B+0.37 A B, \\
E_{\text {лп }}=40.22+3.17 A-25.0 B-3.50 A B+0.17 A^{2}+13.67 B^{2}, \\
h_{3}=312.22+68.33 A-48.33 B+10.0 A B-108.33 A^{2}-8.33 B^{2}, \\
b_{3}=9988.89+783.33 A-583.33 B+325.0 A B-983.33 A^{2}+116.67 B^{2}, \\
\alpha_{3}=6.98+2.0 A-0.83 B+0.17 A B-2.27 A^{2}-0.067 B^{2}, \\
H R C=51.93+2.45 A+1.10 B+0.37 A B-1.55 A^{2}+0.10 B^{2},
\end{gathered}
$$

Accordingly, linear and quadratic regression equations (experimental models) for the actual values of factors have the form:

$$
\begin{gathered}
E_{\text {ли }}=-77,30+0,13 T+0,77 S-1.0 \cdot 10^{-3} \mathrm{TS}, \\
h_{3}=-591.74+0.71 T-4.59 \mathrm{~S}+2.85 \cdot 10^{-3} \mathrm{TS}, \\
b_{3}=6862.77+2.83 T-129.59 S+0.092 \mathrm{TS}, \\
\alpha_{3}=-23.64+0.02 T-0.08 S+5.0 \cdot 10^{-5} \mathrm{TS}, \\
H R C=16.78+0.02 T-0.11 S+1.07 \cdot 10^{-4} \mathrm{TS}, \\
E_{\text {лn }}=12.61+0.04 T-0.21 S-1.0 \cdot 10^{-3} \mathrm{TS}+3.40 \cdot 10^{-5} T^{2}+5.46 \cdot 10^{-3} S^{2}, \\
h_{3}=-36200.32+56.87 T-3.99 S+2.85 \cdot 10^{-3} \mathrm{TS}-0.02 T^{2}-3.33 \cdot 10^{-3} S^{2}, \\
b_{3}=-3.15 \cdot 10^{-5}+512.56 T-137.99 S+0.09 T S-0.20 T^{2}+0.04 S^{2}, \\
\alpha_{3}=-768.41+1.19 A-0.07 B+5.0 \cdot 10^{-5} A B-4.62 \cdot 10^{-4} A^{2}-2.66 \cdot 10^{-5} B^{2}, \\
H R C=-492.12+0.82 T-0.12 S+1.07 \cdot 10^{-4} T S-3.16 \cdot 10^{-4} T^{2}+4.0 \cdot 10^{-5} S^{2},
\end{gathered}
$$

The above obtained mathematical models (Equations 4-13) for the coded factors that associated with the coded LTH process regimes and experimental models (Equations 14-23) for the actual factors that associated with the actual (experimental) values of LTH process regimes. Thus, obtained the quadratic regression models (Equations 9-13 and 19-23) based on above mentioned the ANOVA characterized by high accuracy and can be used to control the energy density of the laser beam, hardening depths, hardening width, hardening angle and surface hardness of the tool steel AISI D2 depending on the heating temperature and feed rate of the treated surface.

Fig. 4 shows the effect of the laser transformation hardening process regimes on the energy density of the laser beam. Energy density magnitudes of the laser beam are directly related to power and diameter of the laser beam, as well as the feed rate of the treated surface (Formula 1).
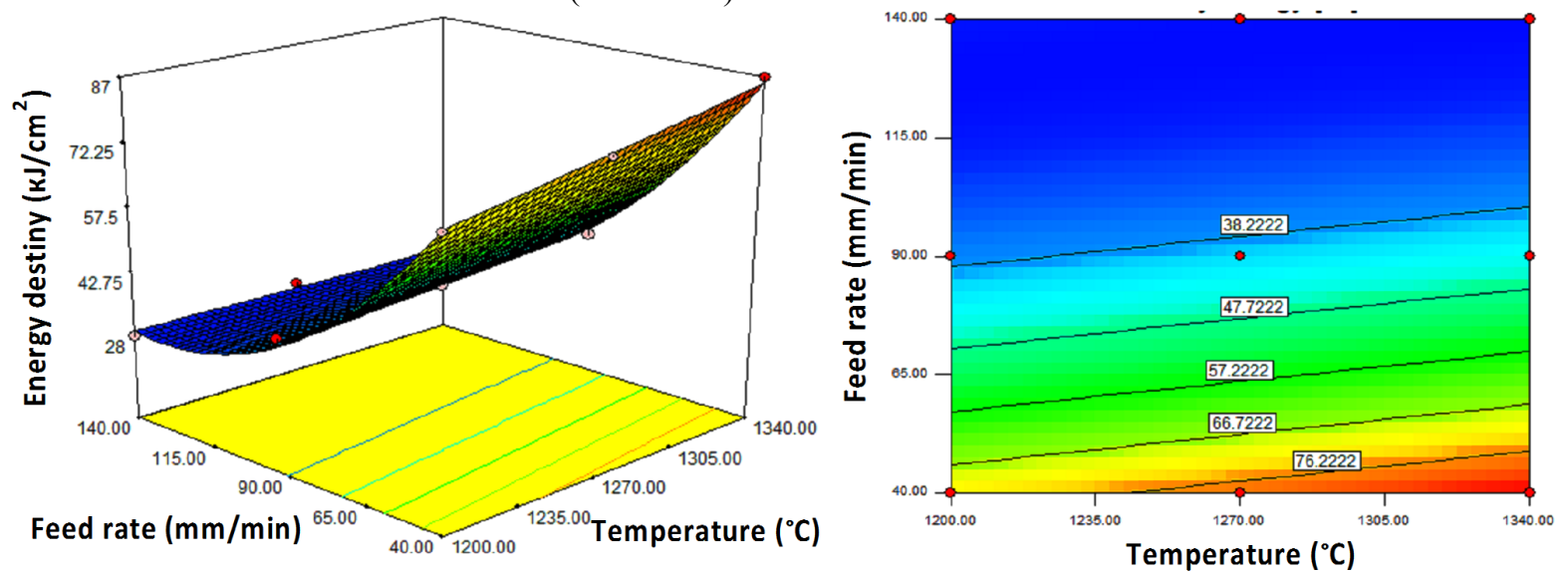

Fig. 4. Response surface and contour plot for effect of heating temperature and feed rate of the treated surface on energy destiny at LTH of the tool steel AISI D2 



Fig. 5. Response surface and contour plot for effect of the heating temperature and feed rate of the treated surface on hardening depths (a), hardening width (b), hardening angle (c) and surface hardness (d) at LTH of the tool steel AISI D2 
The laser power magnitudes were determined by means of implementation the proportional-integral-differential controller and special software. The energy density magnitudes of the laser beam are significantly reduced with increasing the feed rate of the treated surface (Fig. 4). Increasing the heating temperature indicates a slight increment the energy density of the laser beam. In addition, the largest the energy density magnitudes of the laser beam are focused at maximum heating temperature and minimum velocity processing (Fig. 4 right).

Response surface and contour plot to determine the effect of the heating temperature and feed rate of the treated surface on hardening depths, hardening width and angle, as well as surface hardness at LTH of the tool steel AISI D2 are presented in Fig. 5. The previous experimental studies showed that at the heating temperature below $1200{ }^{\circ} \mathrm{C}$ and specimen feed rate $40 \ldots 140 \mathrm{~mm} / \mathrm{min}$ wasn't found the heat affected zone. The hardening depth of the surface layer is approximately 130 microns (surface hardness $\sim 45 \mathrm{HRC}$ ) at the heating temperature of $1200^{\circ} \mathrm{C}$ that is insufficient at the working (exploitation) of products in extreme conditions. The temperature heating enhancement to $1270{ }^{\circ} \mathrm{C}$ caused increase both the geometrical parameters of the laser hardened zone and the surface hardness (Fig. 5). However, at the heating temperature to $1340{ }^{\circ} \mathrm{C}$ is observed a slight decrease in hardened zone parameters in comparison with heating temperature $1270{ }^{\circ} \mathrm{C}$. It may be related that at these LTH regimes of the investigated steel occurs excessive heating of the surface. Herewith, both surface hardness ( HRC 52) and microhardness in cross section of the surface layer (Fig. 6a) almost unchanged.
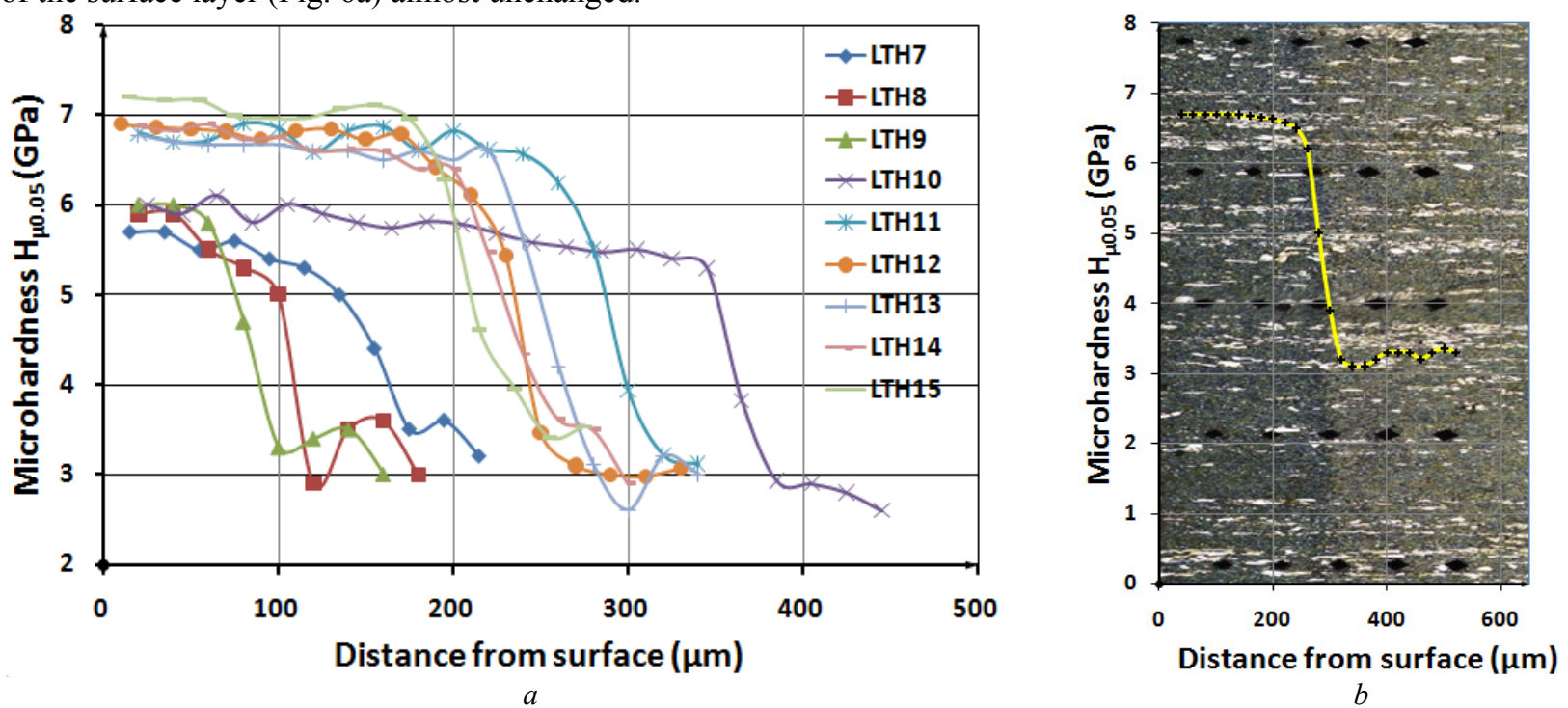

$b$

Fig. 6. Microhardness profiles along the track depth (a) at LTH of the tool steel AISI D2 and microhardness profile along the track depth (b) at the optimum regime (heating temperature $1270{ }^{\circ} \mathrm{C}$ and feed rate of the treated surface $90 \mathrm{~mm} / \mathrm{min}$ )

Furthermore, it was found that at laser heat treatment is observed reduction hardened zone parameters and increase the surface hardness with increasing the velocity processing $(S=140 \mathrm{~mm} / \mathrm{min})$ due to decreasing the cooling rate of subsurface layers (Fig. 5, Table 4). It promotes to creating more homogeneous microstructure of the hardened layer. Despite the better surface hardness, hardened zone has insufficient hardening depth $(\sim 240 \mu \mathrm{m})$ at the maximum velocity processing. The highest the surface hardness magnitudes are observed at the maximum heating temperature and feed rate of the treated surface (Fig. $5 \mathrm{~d}$ right).

Thus, the laser transformation hardening process of the tool steel AISI D2 using the fiber laser with scanner should implement at the heating temperature not more than $1300{ }^{\circ} \mathrm{C}$ and feed rate of the treated surface about $90 \mathrm{~mm} / \mathrm{min}$ for ensuring full austenitization heated surface layers (Fig. 6b). The results in work [12] confirm that defined the optimum LTH regimes the studied steel to avoid melting surface. In addition, cracks in the hardened subsurface layer by scanning laser beam are not found.

\section{Conclusions}

The relationship of technological input LTH regimes at the action of laser beam scanning on change the hardening depth, hardening width, and hardening angle, as well as surface hardness of the tool steel AISI D2 using multifactor experiment with elements of the analysis of variance and regression equations was determined.

The level of effect of the heating temperature and feed rate of the treated surface on the energy density of the laser beam, hardening depths, hardening width, and hardening angle, as well as surface hardness at LTH of the tool steel AISI D2 was established. The desired hardened depth and surface hardness of LHT process can be achieved by means of the developed quadratic models. According to ANOVA, the heating temperature is the main factor affecting on the hardened depth and surface hardness.

The optimum magnitudes of the heating temperature $\left(1270{ }^{\circ} \mathrm{C}\right)$ and feed rate of the treated surface $(90 \mathrm{~mm} / \mathrm{min})$ for laser transformation hardening of the tool steel AISI D2 using fiber laser with scanner were defined. 


\title{
Вплив лазерного термозміцнення на особливості зони зміцнення та твердість поверхні інструментальної сталі Х12МФ
}

\author{
Д.А. Лесик, В.В. Джемелінський, С. Мартінез, А. Ламікіз, О.О. Данилейко, В.В. Хижевський
}

Анотація. Визначено взаємозв'язок вхідних технологічних режимів лазерного термозміцнення на зміну глибини, иирини $i$ кута зміџнення, а також твердості поверхні інструментальної сталі Х12МФ, з використанням багатофакторного експерименту із елементами аналізу дисперсії та рівнянь регресії. Проиес лазерного термозміцнення реалізовано шиляхом контролю температури нагрівання з використанням волоконного $\mathrm{Nd:YAG} \mathrm{лазера} \mathrm{з} \mathrm{сканатором,} \mathrm{пірометра} \mathrm{та}$ пропориійно-інтегрально-диферениіального контролера. Розроблено лінійні та квадратичні регресійні моделі, а також побудовано поверхні відгуків для визначення впливу температури нагрівання та швидкості переміщення оброблюваноі поверхні на густину енергї лазерного променя, глибину, ширину і кут зміцнення, а також твердість поверхні. Показано, щьо основний вплив на величину густини енергї лазерного променя має швидкість лазерної обробки, а на геометричні параметри зони лазерного зміинення та твердості поверхні - температура нагрівання. Визначено оптимальні значення температури нагрівання $\left(1270{ }^{\circ} \mathrm{C}\right)$ та швидкості переміщення оброблюваної поверхні (90 мм/хв) для лазерного термозміцнення сталі Х12МФ при використанні волоконного лазера з сканатором.

Ключові слова: лазерне термозміцнення; поверхневий шар; зона зміцнення, твердість; інструментальна сталь Х12МФ

\section{Влияние лазерного термоупрочнения особенности зоны укрепления и твердость поверхности инструментальной стали Х12МФ}

\author{
Д.А. Лесик, В.В. Джемелинский, С. Мартинез, А. Ламикиз, О.О. Данилейко, В.В. Хижевский
}

\begin{abstract}
Аннотация. Определена взаимосвязь входных технологических режимов лазерного термоупрочнения на изменение глубины, иирины и угла упрочнения, а также твердости поверхности инструментальной стали Х12МФ, с использованием многофакторного эксперимента с элементами анализа дисперсии и уравнений регрессии. Процесс лазерного термоупрочнения реализовано путем контроля температуры нагрева с использованием волоконного Nd:YAG лазера с сканатором, пирометра и пропориионально-интегрально-дифференциального контроллера. Разработаны линейные $u$ квадратичные регрессионные модели, а также построено поверхности отзывов для определения влияния температуры нагрева и скорости перемещения обрабатываемой поверхности на плотность энергии лазерного луча, глубину, ширину и угол упрочнения, а также твердость поверхности. Показано, что основное влияние на величину плотности энергии лазерного луча имеет скорость лазерной обработки, а на геометрические параметры зоны лазерного упрочнения $и$ твердости поверхности - температура нагрева. Определены оптимальные значения температуры нагрева $\left(1270{ }^{\circ} \mathrm{C}\right) \mathrm{u}$ скорости перемещения обрабатываемой поверхности (90 ми/мин) для лазерного термоупрочнения стали Х12МФ при использовании волоконного лазера с сканатором.
\end{abstract}

Ключевые слова: лазерное термоупрочнения; поверхностный слой; зона упрочнения, твердость; инструментальная сталь Х12MФ

References

1. $\quad$ Poprawe, R. (2011), Tailored Light 2. Laser application technology, Springer-Verlag Berlin, Heidelberg, pp. 173-241.

2. Ismail, M.I.S., Taha, Z. (2014), Surface hardening of tool steel by plasma arc with multiple, Inernational Journal Technol, Vol. 5,No 1, pp. 79-87, DOI: https://doi.org/10.14716/ijtech.v5i1.156

3. Zenker, R. and Buchwalder, A. (2013), Electron beam surface hardening, ASM International, Vol. 14, pp. $462-475$.

4. Kovalenko, V. (1998), Ways to intensify laser hardening technology, CIRP Annals - Manufacturing Technology, Vol. 47, pp. 133-136.

5. Martinez, S., Lamikiz, A., Ukar, E., Tabernero, I. and Arrizubieta, I. (2016), Control loop tuning by thermal simulation applied to the laser transformation hardening with scanning optics process, Applied Thermal Engineering, Vol., pp. 49-60.

6. Li, C., Wangn, Y., Han, B. and Rena, L. (2011), Microstructure, hardness and stress in melted zone of 42CrMo steel by wideband laser surface melting, Optics and Lasers in Engineering, Vol. 49, pp. 530-535.

7. Kusinski, J., Kac, S., Radziszewska, A., Rozmus-Gornikowska, M., Major, B., Marczak, J. and Lisiecki, A. (2012), Laser modification of the materials surface layer - a rewire paper, Technical Sciences, Vol. 60, pp. 710-728.

8. Rozmus-Gornikowska, M., Kusinski, J. and Blicharski, M. (2010), Laser shock processing of an austenitic stainless steel, Archives of Metallurgy, Vol. 55, pp. 635-639.

9. Lisovsky, A.L. and Pletenev, I.V. (2008), Laser hardening of the die tool, Bulletin of the Belarusian-Russian University, No. 3(20), pp. 90-99.

10. Leech, P.W. (2014), Laser surface melting of a complex high alloy steel, Materials and Design, Vol. 54, pp. 539-543.

11. Golovko, L.F. and Lukyanenko, S.O. (2009), Laser technology and computer simulation [Lazerni tehnologiyi ta komp'yuterne modelyuvannya], Vistka, Kyiv, Ukraine.

12. Lesyk, D.A., Martinez, S., Dzhemelinskyi, V.V., Mordyuk, B.N., Lamikiz, A. and Prokopenko, G.I. (2015), Surface microrelief and hardness of laser hardened and ultrasonically peened AISI D2 tool steel, Surface \& Coating Technology, Vol. 278, pp. 108-120, DOI 10.1016/j.surfcoat.2015.07.049. 